\title{
0 povo conta a sua mídia: a construção da Rádio Comunitária Nova Geração de Jatatizinho (PR) ${ }^{1}$
}

\section{The people counts its media: the construction of the Communitarian Radio Nova Geração of Jataizinho (PR)}

\author{
EdUARDO YUII YAMAMOTO2 \\ Prof. Universidade Estadual Paulista (UNESP), Faculdade de Arquitetura, \\ Artes e Comunicação (FAAC), Departamento de Pós-Graduação. \\ E-mail: yudieduardo@bol.com.br
}

\section{Resumo}

0 objetivo deste artigo é recuperar a história da construção da Rádio Comunitária Nova Geração de Jatatizinho (PR), a partir da memória dos habitantes dessa localidade. Como metodologia, a pesquisa orienta-se pela interpretação de uma historiografia oral, obtida através de entrevistas e com a formação de dois grupos naturais de discussão. Tal narrativa é estrutura em três momentos: a construção dessa mídia, seu momento de idolatria e sua amortização na vida da comunidade. A articulação dos dados da pesquisa aponta para um fator importante e que deve ser relevado para a compreensão da história dessa mídia comunitária: a existência de uma cultura midiática em Jataizinho. Palavras-chave: Comunicação Comunitária, História oral, Cultura midiática, Rádio Comunitária Nova Geração, lataizinho.

'Texto indicado para a seção relatos de pesquisa.

2 Jornalista e especialista em "Comunicação Popular e Comunitária" pela Universidade Estadual de Londrina (UEL-PR). Mestrando do programa de pós-graduação em "Comunicação Midiática", da Universidade Estadual Paulista (UNESPBauru/SP). Pesquisador do grupo "Mídia e Sociedade" (CNPq). Bolsista Capes.

${ }^{3}$ PEREIRA, Vitor Sorano; YAMAMOTO, Eduardo Y. Sujeito: Som: Representação: um estudo de recepção da Rádio Nova Geração de Jataizinho. Monografia apresentada como Trabalho de Conclusão de Curso (Comunicação Social: hab. Jornalismo). Universidade Estadual de Londrina (PR), 2004.

\section{Introdução}

A história desse trabalho começa com um equívoco. A iniciativa vem de um sentimento de incompletude de pesquisador insatisfeito querendo reescrever uma outra versão histórica que dirimisse algumas distorções de uma pesquisa anterior intitulada "Sujeito: Som: Representação: um estudo de recepção da Rádio Nova Geração de Jataizinho ${ }^{3}$ ", em que os autores pretenderam um misto de pesquisa de recepção e leitura crítica de produtos midiáticos. Naquele momento, o propósito da pesquisa estava centrada numa descrição etnográfica do cotidiano da comunidade de Jataizinho, a partir da qual se construiria um quadro de relações que pudesse explicar a atual audiência da rádio. Pela pesquisa estar mais interessada na recepção - como o subtítulo pode indicar algumas informações (observações de campo) foram suprimidas, em parte pela exiguidade do tempo de elaboaração da monografia, em parte por conta dos próprios objetivos da pesquisa. A intenção era conhecer os limites (técnicos, políticos, econômicos e culturais) desse meio de comunicação massivo - fatores que pudessem influenciar em sua audiência - além das possibilidades de uso da rádio pelos grupos da base, como instrumento de coesão e participação. Depois de algum tempo, e longe daquela realidade, uma inquietação se abateu sobre o pesquisador: os resultados dessa pesquisa pareciam confirmar uma hipótese que tínhamos a priori, qual seja, a reprodução, naquela comunidade, de uma forma ideológica de 
pensamento. Aimpressão que ficava era de uma audiência alienada.

A inquietação, no entanto, vinha de uma incoerência dos próprios resultados da pesquisa: elas pareciam contrastar com algumas observações que havíamos feito durante a coleta de dados. Todavia, a questão era ainda mais simples. Para compreender a comunidade na qual estávamos imersos, e mesmo para confrontar as teorias com as quais nos seríamos, deixávamos de analisar as relações profundas de significação das falas (e fatos), caindo numa interpretação superficial daquela realidade. A noção de cultura, tal como defende Douglas Kellner (2001, p. 9), apoiada numa espécie de totalização da vida pelos meios de comunicação, parecia nos dar algumas pistas para resolução de um problema aparentemente simples daquela audiência: a vida daquela comunidade estava subordinada a uma relação de poder vertical estabelecida no âmbito da cultura, essa por sua vez, era uma cultura dominada.

Há uma cultura veiculada pela mídia cujas imagens, sons e espetáculos ajudam a urdir o tecido da vida cotidiana, dominando o tempo de lazer, modelando opiniões políticas $e$ comportamentos sociais, $e$ fornecendo o material com que as pessoas forjam sua idenditade.

Foi como uma forma de exorcizar alguns fantasmas que rondavam aquela pesquisa, que se procurou através desse artigo questionar os resultados daquele primeiro trabalho. Como autocrítica, e adotando o que Nietzsche designou de uma "genealogia" da cultura moderna especificamente sobre sua crítica ao objetivismo científico - este trabalho volta à própria gênese de seu discurso fundador: a revisão de sua

Veículos em Perspectiva

própria cientificidade, o estatuto de uma verdade legitimada.

Assim, o que a história desse artigo pretende fazer é uma espécie releitura desses dados esquecidos, excluídos pela hierarquia de uma "ordem do discurso" (FOUCAULT, 1999, p. 7), guardados empoeirados que agora tentamos polir, ressuscitar à luz de um diálogo com a história.

Esta releitura, contudo, não invalida aquele primeiro trabalho. $\mathrm{O}$ problema que se coloca aqui diz respeito à interpretação, e não a uma forma de pensamento falsa ou verdadeira. Justamente porque esta ambigüidade é impossível de se saber ao certo.

A fixação dessa pesquisa no âmbito da cultura é estratégica: em primeiro lugar, porque a cultura constitui um espaço em que idéias sociais surgem e cristalizam num todo social, garantindo a legitimidade da ação do sujeito; em segundo lugar, porque a própria concepção de poder tem na cultura as regras para o seu exercício legítimo.

É nesse sentido que afirmamos a validade de ambas as pesquisas. Como defende Foucault, o exercício de poder pode ser equacionado numa relação vertical de dominação, como também nas micro-ações (horizontais) entre os indivíduos no interior de uma mesma classe social:

\begin{abstract}
"Os poderes se exercem em níveis variados e em pontos diferentes da rede social e neste complexo os micro-poderes existem integrados ou não ao Estado [...]" (MACHADO)+ Assim, depreendemos que "[...] o poder não é principalmente manutenção e reprodução das relações econômicas, mas acima de tudo uma relação de força" (FOUCAULT, 1999, p. 175).
\end{abstract}

Geertz (1976), em seu livro “A
- MACHADO, Roberto. Por uma genealogia do poder. In.: FOUCAULT, Michel. Microfísica do poder. Rio de Janeiro (RJ): Graal edições, 1999, p. XII. 
interpretações das culturas", apresenta a concepção de cultura não como um conjunto predeterminado de conceituações cujo ofício do antropólogo é confirmá-los mediante uma mensuração positiva. A cultura, para Geertz, constitui-se como uma interpretação fenomenológica, a descrição dessa camisa de força que angustia o homem e marca o drama de sua existência na sociedade.

\begin{abstract}
Acreditando, como Max Weber, que o homem é um animal amarrado a teias de significados que ele mesmo teceu, assumo a cultura como sendo essas teias e a sua análise; portanto, não como uma ciência experimental em busca de leis, mas como uma ciência interpretativa, à procura do significado. É justamente uma explicação que eu procuro, ao construir expressões sociais enigmáticas na sua superficie. Todavia, essa afirmativa, uma doutrina numa cláusula, requer por si mesma uma explicação (GEERTZ, 1978, p. 15).
\end{abstract}

A presença de um meio de comunicação numa dada formação social - como é o caso específico dessa pesquisa - implica uma outra configuração sócio-cultural, posto que esse meio entra como uma variável (condicionante) na reprodução daquela realidade. A centralização dessa pesquisa sobre essa nova configuração sugere a utilização de um aporte teórico (semiótica) que atue na interface desse fenômeno, e nos ofereça uma interpretação de uma cultura influenciada, em outras palavras, midiatizada.

Não resta dúvida que muitas teorias da cultura, em áreas as mais diversas, apresentam características nitidamente semióticas; principalmente quando explicam a dimensão cultural através dos sistemas simbólicos de uma dada formação social. [...] enquanto nas conhecidas ciências humanas os estudos da cultura são utilizados para compreender os agentes dos processos culturais, o homem, a semiótica, por seu lado, coloca ênfase nos modos como esses sistemas são processados para produzirem sentido e serem comunicados. (SANTAELLA, 1996, p. 27).

\section{Uma cultura midiática?}

A intenção de se construir uma história comunitária a partir de fragmentos de memória e entrecruzamento de diálogos, se passará em termos de uma interpretação da cultura de Jataizinho. A experiência marca um mergulho de 3 meses no cotidiano da cidade. Antes disso, e debruçado sobre a literatura sóciogeográfica da região, a pesquisa pode observar algumas marcas que a distingue de outras cidades da região: Jataizinho, uma cidade de aproximadamente 11 mil habitantes ao norte paranaense (a $350 \mathrm{~km}$ da capital Curitiba), em que a maioria das pessoas tem uma renda bastante inferior em relação à média nacional. A cidade não possui nenhum potencial econômico e por isso seus habitantes trabalham fora da cidade, naquelas circunvizinhas (Londrina, Ibiporã, Cambé, etc). Como peculiaridade, Jataizinho possui apenas uma emissora de rádio como veículo de comunicação local, conforme alguns entrevistados, construída por uma necessidade dos próprios moradores.

A questão que se colocava àquela cultura transitava num plano antropológico; especificamente, girava em torno da construção da rádio comunitária: por que uma mídia é tão importante numa comunidade 
que se acha privada dos recursos mais básicos? Essa dúvida mobilizou a imersão naquela realidade, a partir de uma leitura histórica que pudesse explicitar as condições políticas econômicas e culturais que viabilizaram a construção da rádio. Tratando-se de um canal comunicativo construído pelos esforços da própria população, observou-se na Rádio Comunitária Nova Geração de Jataizinho (PR) uma especificidade dentre outras emissoras comunitárias no que se refere à mobilização, participação, e elaboração do material midiático.

Se a base desse fenômeno estiver ancorada no que se poderia chamar de uma cultura midiática, esse fato ilustraria a visibilidade da comunicação na atualidade - e a improvável desconsideração da dimensão comunicativa nas análises sociais em pequenas localidades, desde que sob tais condições.

A evidência a partir da qual se permite falar em cultura midiática é o fato da existência de um novo lugar social em que se opera uma outra forma de sociabilização. Nesse espaço as relações sociais são estabelecidas a partir da mediação, isto é, segundo um suporte materializador de discursos, que para os propósitos dessa pesquisa será denominado mídia. O uso dessa cultura no estabelecimento de relações sociais irá depender tanto dos códigos comunicativos utilizados, como do próprio aparato simbólico, em cuja base os discursos se sustentam. A idéia de cultura midiática, desse modo, surge para compreender a constituição de uma determinada formação social segundo seus processos comunicativos: os mecanismos e estratégias de linguagem. A relevância de um aprofundamento teórico nesse ambiente midiático dá-se tanto pela visibilidade da comunicação na

Veículos em Perspectiva sociedade contemporânea, quanto pela importância que esta assume no cotidiano das pessoas.

Para a compreensão da cultura midiática, contudo, não bastaria tão somente a leitura dos processos de produção de sentido por um sistema simbólico, mas também os desdobramentos e projeções desses produtos comunicativos sobre a sociedade. Isso porque os vários interlocutores que participam desse processo compartilham não apenas um mesmo repertório cultural, mas também agem sobre esse processo, alterando seus próprios contornos individuais e modificando a cultura da sociedade como um todo.

Essas estratégias de poder dentro da cultura midiática estão em conformidade com uma nova configuração social. Não é sem razão que a ênfase sobre à características desse ambiente de socialização chamado mídia indique a necessidade de uma descrição dos aspectos culturais re-significados que a legitima enquanto tal.

O pressuposto de uma cultura midiática sugere, doravamente, a hipótese de um deslocamento tempoespacial, de acontecimentos reais para acontecimentos midiáticos (submetidos à lógica da mídia, em seu tempo e espaço). Essa transposição marca o abandono dos tradicionais espaços públicos em favor de uma arena midiática, uma espécie de Ágora contemporânea.

Recapitulando, e para simplificar os pressupostos que validariam a existência de uma cultura midiática naquela comunidade, a pesquisa elencou: 1) a influência de fatos midiáticos no desdobramento do cotidiano dos moradores; 2) a construção de uma identidade política a partir da mídia; 3) a importância que a comunicação (técnica ou não) assume na comunidade.

A construção de realidades em

Comunicação \& Informação v. 11 , n. 1: p. 44-56 - jan./jun. 2008 
torno de acontecimentos midiáticos, se por um lado dá a dimensão e importância da esfera comunicativa na contemporaneidade, por outro lado apresenta a manipulação de fatos reais por parte de alguns grupos que utilizam uma mídia comunitária para finalidades particulares. Isso será evidenciado pela atual situação dessa Rádio, sofrendo as sanções do poder municipal e descrédito de seu público.

\section{A experiência em Jataizinho}

A chegada em Jataizinho pode ser considerada como sendo o momento em que se cruza o rio Tibagi. A porta de entrada é o que lá se considera o centro da cidade, e que se desenvolveu à margem desse mesmo rio. Há uma avenida principal rodeada por quarteirões de ruas largas, num raio de 1 a 2 quilômetros, limitados pela rodovia, pela margem do rio Tibagi e pela margem do córrego Jataizinho. A praça principal é o marco-zero da cidade, ela faz frente à sede da Igreja Católica ao lado da qual está instalada a Rádio Comunitária Nova Geração.

A maior parte da população, contudo, se encontra do outro lado do córrego Jataizinho. O vale que abriga o centro dá lugar, ao cruzarse este afluente, a um emaranhado de pequenos morros de média inclinação e várzeas. Aí se localiza a periferia da cidade. Nesse espaço, observam-se divisões entre os diversos conjuntos que constituem a área. Em um dos bairros, a Vila Pavão, a maioria das moradias é feita de madeira e em muito lembram as favelas dos grandes centros, também devido ao fato de se localizar em um morro.

Existe ainda uma zona rural onde vivem em torno de 1.000 pessoas, segundo dados do IBGE (Instituto Brasileiro de Geografia e Estatística) em 2001. A falta de transporte, aliado ao difícil acesso à tais localidades, impediu que a coleta de informação ocorresse in locus. Essa dificuldade pode ser suprida pelas entrevistas com adolescentes e adultos que estudavam no período noturno, enriquecendo as informações sobre a construção da rádio, sua audiência e representações na comunidade.

Outro fato importante é que algumas informações oficiais puderam ser confrontadas no mergulho e percepção daquele cotidiano: embora o Censo de 2000 tenha indicado que $15 \%$ da população de Jataizinho seja analfabeta, as conversas informais com os habitantes revelaram que uma fatia muito maior não possuía a capacidade de compreender o que lia. Isso pode ser constatado pelo fato de muitas pessoas adultas ou idosas revelarem ter estudado apenas até o $2^{\circ}$ ou $3^{\circ}$ ano do ensino básico, segundo eles "o ensino antigo". Essa observação, apenas a título de sondagem, inviabilizaria qualquer possibilidade de pesquisa por questionários. Nesse caso, o uso do código oral atendeu eficientemente às necessidades da pesquisa.

O mês de outubro de 2004 foi movimentado politicamente em todo país, devido às eleições para o poder municipal. Em Jataizinho essa movimentação ganhava visibilidade principalmente na periferia. Caminhões de som e comícios públicos compunham ali uma grande festa popular: as eleições. Conforme a pesquisa irá apresentar mais adiante, o aspecto político irá permear o cotidiano dessa comunidade a partir de um fato midiático.

\section{No ar... a Rádio Comunitária Nova Geração de Jatatizinho}

A instalação da Rádio Comunitária Nova Geração em Jataizinho 
está profundamente associada à Igreja Católica da cidade, representada nas pessoas de Frei Adelino Frigo e Odemir Marques.

Assim como acontece em muitos pequenos municípios, os alto-falantes da sede da Igreja Católica constituíam o veículo comunicativo de alcance público em Jataizinho. Por meio deles eram anunciados os óbitos da cidade, as informações oficiais, além de outros serviços de utilidade pública. Além de cumprir precariamente o papel de meio de comunicação de massa, a igreja serviu como espaço para o encontro entre Marques e Frigo. A confluência dos interesses de ambos vai dar início às primeiras tentativas de implementação de uma estação de rádio na cidade.

A concessão para a rádio comunitária foi outorgada em 2001, mas a rádio já funcionava, clandestinamente ou em caráter experimental (instância anterior à regulamentação) desde 1996, de modo intermitente. A cada transmissor lacrado, um novo era adquirido, garantindo-se a continuidade da emissora. A constituição da rádio que se tornaria a comunitária Nova Geração, portanto, aconteceu antes da liberação oficial.

A construção do prédio - onde está instalada até hoje - bem como a compra dos materiais foram realizadas com recursos financeiros e humanos da própria comunidade. No dia 10 de agosto de 2001, fundouse a rádio comunitária Nova Geração. Segundo depoimento do diretor, Odemir Marques:

Respondendo processo de uma e nós já colocamo a outra rádio no ar. Só que nesse ínterim nós já começamos a construir este salão aqui (...) todinho ajudado pela comunidade. Um doava tijolo, o outro dava areia, cal, vitrô, dez barras de ferro... $E$ (...) tinha gente que dava dinheiro, $R \$ 25$ (...). Então todo mundo ajudou, prefeitura, igreja, comunidade. $E$ o pessoal trabalhou de graça também. $O$ pessoal vinha trabalhar, engenheiro doou serviço, fazia $a$ parte de engenharia. A prefeitura cedeu um funcionário por três meses. Então foi uma coisa bonita... e o negócio pegou mesmos.

No período de construção da rádio, e mesmo durante a fase de seu funcionamento legal, a rádio contava com ampla participação dos moradores que davam sugestões para a criação de novos quadros e programas diferenciados. Até o momento de sua crise financeira, a programação da Rádio Comunitária Nova Geração esteve sempre aberta à participação voluntária de indivíduos da comunidade.

Atualmente, os programas produzidos são essencialmente musicais. $\mathrm{Na}$ ausência de uma programação exclusivamente jornalística, as informações e serviços de utilidade pública são veiculados entre uma música e outra e se pautam pelos conhecimentos e interesses de cada locutor/produtor, assim como os estilos musicais. Alguns programas obtêm certo sucesso e continuam por algum tempo. Outros têm fôlego curto, ou por desinteresse do próprio produtor ou por não encontrarem respaldo popular. No primeiro grupo, destacam-se os locutores Claudinei de Oliveira Cabral (o Din-Din) e Anderson Oliveira - que ocupam as manhãs semanais; os programas religiosos (católicos e evangélicos, principalmente); a Rádio Moleca produzido por crianças com apoio do Conselho Tutelar de Jataizinho; e o Love Line - coordenado por Anderson Oliveira.

As boas relações que a rádio
${ }^{5}$ Todos os depoimentos deste trabalho foram ligeiramente alterados para facilitar a compreensão. Não se tentou adequá-los à gramática normativa, afim de não comprometer a expressividade do texto. 
nutria com o poder público local transformaram-se em atritos no final do mandato (2004) da prefeita Teresinha de Fátima Sanches (PMDB-PR). A suposta má administração municipal desencadeou uma série de críticas. Estas eram levadas ao ar pelos próprios cidadãos nos microfones da rádio Nova Geração. Até então, a prefeitura se encarregava de pagar as contas de água e energia elétrica da emissora, apoio que foi retirado ao mesmo tempo em que a ajuda financeira.

Segundo Marques, os conflitos com a administração minaram também o apoio do pequeno comércio local, enfraquecido pela situação financeira da cidade:

Aí tinha alguns comerciantes que faziam apoio na rádio e que eram diretamente ligados a ela [a prefeita] que aíforam tirando também $e$ nós continuamos mantendo a rádio. Enfraquecidos, mas mantemo (...) Aí, nos intermediário [entre 2001 e 2004] a rádio foi enfraquecendo, tem um relatório de 2003 do IBGE que mostra que $17 \%$ da nossa população vive abaixo da linha da pobreza. A cidade sendo pobre, a rádio é pobre, tudo é pobre. O comércio é pobre... (MARQUES, depoimento colhido em outubro de 2004).

O estopim dessa crise aconteceu em 2003, durante o programa ValeTudo, com a veiculação de uma matéria sobre a suposta instalação de um presídio em Jataizinho:

Quando a gente deu a matéria, tudo que é os deuses virou contra a rádio. No outro dia depois que deu esse problema, aí já veio os fiscais da Anatel [Agência Nacional de Telecomunicações] solicitar cópia de fita. Eles levaram a fita e não deu em nada. Aí dedaram nós pro Ecad [Escritório Central de Arrecadação], ecad é o direitos autorais das músicas que toca, é um imposto que paga. Tudo na mesma data (MARQUES, depoimento dado em outubro de 2004).

Entretanto, a apuração do programa Vale Tudo apresentado por Claudinei de Oliveira Cabral (DinDin) no dia 19 de agosto de 2003, aponta para uma abordagem tendenciosa e parcial do assunto. A matéria, veiculada pelo diário Folha de Londrina, indicava que Jataizinho, por meio da prefeita, havia se disponibilizado a receber um presídio industrial estadual. Uma enquete foi montada durante o programa e no decorrer do mesmo os ouvintes ligavam para manifestar a sua insatisfação frente à instalação do presídio. $\mathrm{O}$ direito de resposta da prefeita, que também ligou para participar da enquete, era interrompido por intimidações e ironias do apresentador. Esse fato foi assim transcrito:

Din Din: Sim. Alô? Doutora Teresinha?

Prefeita: Sim?

Din Din: A senhora não está ouvindo a rádio?

Prefeita: Eu estou ouvindo sim. E eu estou ligando porque eu gostaria de desmentir mais esta mentira que vocês estão colocando no ar. Que a respeito de reunião que eu participei com prefeitos e ofereci o município para instalação de presídio. Eu nunca participei de reunião nenhuma. $E$ ontem à tarde quando a Folha de Londrina me ligou e me disse que existia essa história, eu deixei bem claro... $e$ vocês podem ler isso, que se isso chegasse a ser uma realidade, um oferecimento à cidade de Jataizinho, a comunidade seria consultada... Din Din (entra e corta a 
prefeita): Quem mente aqui... Doutora... Faça o favor... A senhora faça o favor... não, não, peraí, Não a senhora faça o favor, aqui. A senhora está certa em participar... É claro falar, também... Mas então quem mente aqui é a própria Folha de Londrina, um jornal idôneo, um jornal que circula em todo o Estado do Paraná?

Prefeita: Eu acho que não é possível fazer essa enquete porque em nenhum momento...

Din Din: ... e eu vou fazer essa enquête de agora até o fim do nosso programa... Tiago Marques [operador de som], por favor..

Prefeita: ...então faça a enquete, só que a comunidade pode ficar tranqüila, porque em nenhum momento a prefeita fez qualquer movimento neste sentido...

Din Din: Sim senhora.

Prefeita: Boa tarde aos ouvintes... e novamente peço desculpa à nossa comunidade por estar ouvindo tamanha besteira... Boa Tarde.

Din Din: E eu fico feliz da vida em saber que a senhora ouve o meu programa, um abraço... (Desliga o telefone da prefeita) Din Din: Quinze horas e vinte e dois. Saiu na Folha de Londrina e eu coloco no ar... (PROGRAMA VALETUDO, 19/08/2003).

Pelas falas dos ouvintes que ligaram para participar da enquete, verifica-se uma incompreensão da notícia veiculada pelo apresentador, confundindo a audiência. A maioria deles ligava para protestar sobre a falta de emprego na cidade. Ou seja, tangenciava o núcleo da notícia. Se por um lado seja válida a participação e a mobilização social através de um veículo comunitário, por outro, o apresentador se valeu desta movimentação como estratégia política. Isso se torna ainda mais evidente pelo fato do mesmo ter-se lançado neste mesmo período como candidato a vereador da cidade.

Embora a Nova Geração se expresse como ferramenta comunitária de comunicação, a pesquisa verificou que é nítida sua reprodução, em vários aspectos, como veículo massivo comercial. A seguir transcrevemos as falas dos dois principais candidatos ${ }^{6}$ e suas opiniões sobre a rádio comunitária Nova Geração:

Há mais ou menos dois anos quando eles assumiram essa diretoria, eles direcionaram todo o trabalho deles para a minha difamação. Então durante todo esse tempo eu tive que pedir um monte de vezes, fitas, cópias, isso está tudo arquivado [...] Nunca tive direito de resposta, ou espaço na rádio... a gente fez algumas promoções, pra poder manter, consertar transmissor, fazer festa, conseguir patrocínio [...] Parei, parei [de patrocinar a rádio]... Por causa dos ataques pessoais, e por que a prefeitura investindo como entidade pública não tinha benefício nenhum. Nos três últimos anos ela teve um direcionamento unicamente político. Não comunitário, tanto que os programas, cada um tinha um candidato a vereador fazendo o programa. E as pessoas que eram convidadas para entrevistas eram somente as pessoas que seriam candidatas depois. (SANCHES, Teresinha. Depoi-mento dado em outubro de 2004).

Ali [Nova Geração] ficou exclusivamente aquelas pessoas que tinham uma tendência pra determinado candidato. $\mathrm{Na}$ própria diretoria foram colocadas pessoas de um partido... teve um candidato aí que espaço foi aberto pra ele não sei se foi cinco, seis, sete
${ }^{6} \mathrm{~A}$ apuração apontou o pedetista Wilson Fernandes como o novo prefeito eleito, com $38,92 \%$ dos votos válidos. A candidata peemedebista à reeleição, Teresinha de Fátima Sanches, ficou com $21,38 \%$ dos votos. Fonte: Folha de Londrina. Disponível no site: umw.bonde.com.br/eleicoes/mun2004/ 1turno/apuracao/PR/76473.htm. Pesquisa feita em 08.12.2005. 
vezes... Eu não fui convidado nenhuma, entendeu? Então isso é politica. (FERNANDES, Wilson. Depoimento dado em outubro de 2004).

A tendência partidária apresentada foi apontada também por inúmeras pessoas entrevistadas na coleta de dados para a pesquisa, e mesmo durante o grupo de discussão.

"Eu acho que já foi uma coisa [o programa Vale Tudo do dia 19/08/03] que a deixou [Rádio Comunitária Nova Geração] mais baixo..." (Participante 1 do grupo de discussão II).

É interessante observar a naturalidade com que o aspecto partidarismo político emergiu no grupo de discussão, pois apesar da rádio negligenciar "o lado" da prefeita às denúncias do apresentador, e também em outros programas, conforme os respondentes, os participantes sentiram uma lacuna no fato: "a gente também tem que ver o lado de porquê eles [a Prefeitura] não tão querendo ajudar a rádio". (Participante 3 do grupo de discussão II).

Pela recorrência nas falas, os dois aspectos mais importantes assinalados pelos entrevistados foram: o partidarismo político da emissora e sua situação financeira. Esses dois assuntos não são inconciliáveis, mas, ao contrário, relacionam-se segundo as preocupações políticas divergentes na comunidade. Como instrumento comunicativo a serviço da comunidade é evidente os inúmeros conflitos políticos que a perpassam - situação confirmada também em várias outras rádios comunitárias do norte do Paraná?.

Em relação ao problema financeiro da rádio, polarizou-se nos grupos de discussão duas vertentes antagônicas: aquelas que eram a favor da política da rádio, e outra que era contrária. Ambas concordaram que os apoios institucionais, tal como preza a lei que constitui o serviço, deveria ser ignorada a favor da divulgação do comércio local. Nenhum dos dois grupos, entretanto, se prontificou a assumir parte da administração da rádio, seja para captar recursos, seja para participar de seu funcionamento, gerência, ou fiscalização.

Hoje, a Rádio Comunitária Nova Geração sobrevive com um orçamento mensal médio de $\mathrm{R} \$$ 300,00 advindo de cotas de apoio cultural pagas pelo comércio local. A arrecadação é feita pelos próprios locutores e operadores voluntários, que retêm - por acordo com os diretores da rádio - parte das cotas que conseguem arrecadar.

$\mathrm{O}$ atual enfraquecimento moral e financeiro da rádio também afetou a sua grade de programação: poucos programas comandados por locutores e maior parte da progamação reservada à execução constante de músicas.

Da cultura midiática à Ágora contemporânea

Algumas indagações que instigaram a presente pesquisa podem ser resumidas nas seguintes formulações: existiria uma cultura midiática na base das relações sociais da comunidade? Por que uma comunidade se organiza e constrói uma mídia? Por que, depois de um momento de encantamento, a comunidade passa a ver essa mídia com outros olhos? Essa comunidade seria politicamente apática?

Vamos analisar alguns fatos que deverão compor o desenvolvimento dessa narrativa. Talvez fosse equivocado cair na tentação de um julgamento prévio e, desse modo, 
assumir a noção de cultura como algo previsível, definido por força de um sistema totalizante, coerente e acabado. Assim, antes de assumir a perspectiva de uma apatia política a reprodução de um discurso ideológico por parte da audiência este trabalho valida o pressuposto da importância que a dimensão comunicativa adquire nesse espaço. Essa consideração é necessária já que é em torno da construção de canais de comunicação que avaliaremos o estatuto político da comunidade, isto é, o exercício do poder popular. Tal hipótese é validada por duas informações importantes: 1) a construção de uma mídia pelos esforços da própria comunidade, e 2) o fato dos moradores conferirem uma importância simbólica à Mídia, mesmo que esta ostente uma determinada vertente política que não conjuga com os interesses da maioria.

Essa importância simbólica está relacionada ao fato de que, nesses dois grupos políticos divergentes, nenhum deles manifestou-se contra a existência da rádio. Isso pode ser verificado pela recorrência das falas sobre a importância dessa mídia no cotidiano da cidade. Como aspecto positivo, conforme os entrevistados, a pesquisa elencou algumas funções para a rádio: transmissão da missa das 7, divulgação das festividades locais, programação musical fixa, valorização da cidade e dos artistas locais, divulgação do comércio local, promoções, etc.

Por tais atributos podemos conferir à rádio comunitária uma característica ritualística, tal como Baitello Júnior (1999, p. 98) a compreende:

Um dos mais importantes portadores materiais do sistema simbólico chamado tempo, um de seus suportes é a atividade de geração, distribuição e conservação das informações. Nesse contexto desempenha papel de destaque em nossa contemporaneidade a atividade da mídia, os meios de comunicação de massas: sistemas de notícias, desde a sua geração até a sua chegada ao receptor, jornais, emissoras de rádio e televisão, redes, etc. Esses suportes atuam invariavelmente como demarcadores de tempo de vida dos indivíduos, sincronizando suas atividades dentro de um todo maior.

A ritualização (palavra que detém a mesma raiz latina de ritmo) através da mídia, além de marcar temporalmente as atividades da população, presentifica fatos reais através de acontecimentos midiáticos. Nesse caso, suprime-se tempo e espaço (bases da realidade), passando-se a viver num ambiente midiático. Um culto à mídia, por exemplo, pode ser verificado no caso da transmissão da missa das 7. A comunicação mediada pelo aparelho transforma esse mesmo aparelho no próprio objeto de culto. Esse dado pode ser estendido à divulgação de festividades locais, enfatizando a natureza sincronizadora da mídia na reiteração dessa cultura (datas festivas: dia do padroeiro da cidade, aniversário da rádio, etc).

$\mathrm{O}$ aprofundamento no cotidiano da cidade permitiu que se observassem outros canais de comunicação: reuniões com líderes de bairros, circulação de informes sobre as reuniões, ou seja, comunicação oral dialógica. Tais comunicações passam ou não por suportes tecnológicos. Sua eficiência, entretanto, pode ser observada na medida em que analisamos o fato midiático que desencadeou as tomadas de posições políticas na 
comunidade. Antes de desenvolvermos esse episódio, cabe um primeiro apontamento: a comunidade confere importância à mídia, independente dela ser a Rádio Comunitária Nova Geração. Conforme se verificou, a valorização midiática é simbólica e se projeta particularmente sobre a rádio. Foi ela quem abarcou as aspirações e anseios da comunidade num momento histórico específico, culminando em sua construção.

Essa atribuição simbólica, contudo, poderia vir de outros canais de comunicação (seja ele técnico ou não). Dominique Wolton (2004, p. 325) denomina "ideologia técnica" a atribuição de valores positivos aos aparatos tecnológicos de comunicação - tal como faz a comunidade de Jataizinho, no caso da rádio. Essa idéia entra em conformidade com o que a pesquisa considera "encantamento" pela técnica.

[...] a ideologia técnica, apesar de sua aparência modesta [...] combina as três dimensões de toda ideologia: por meio das fantasias a respeito da sociedade da informação, ela veicula um projeto político; por causa de sua dimensão naturalmente antropo-lógica, ela constitui um sistema de crença; pelos seus interesses econômicos, ela é uma ideologia de ação. (WOLTON, 2004, p. 325).

O importante, todavia, é observar se tais características, intrínsecas à comunidade (ritualização da mídia e encantamento pela técnica), estariam relacionadas à existência de uma cultura midiática.

Acerca dessa cultura, em torno da qual se vivencia o cotidiano da cidade, analisemos o impacto de um acontecimento midiático e seu desdobramento na vida da comunidade. O desentendimento da prefeita com o locutor, evento que resultou numa polarização política latente na comunidade, pode ser observada pela agregação de valor em um fato representado. Essa valorização da notícia é atribuída a um episódio gerado no interior da própria mídia. Um enunciado (da Folha de Londrina) suscitou uma interpretação tendenciosa (da rádio comunitária Nova Geração), que por sua vez desencadeou na comunidade a ira contra o poder público municipal. Entre o fato real (a possibilidade de construção de um presídio industrial na cidade, segundo a prefeita) e o fato representado (as conseqüências da instalação do presídio na cidade), existia um hiato que foi preenchido pela política editorial da rádio. Uma disputa política precedente entre a prefeitura e a rádio corrobora para a afirmação de uma divergência política entre ambas na história da comunidade.

A pesquisa verificou uma ênfase acentuada nesse episódio, conforme apontaram muitos entrevistados. No mais, o que importa aqui não é tanto o julgamento da rádio como tendenciosa e parcial, mas como um determinado fato midiático ganha notoriedade nesse espaço. Como veículo de comunicação massiva, a rádio constitui-se como elemento influente no cotidiano dos habitantes. A repercussão desse acontecimento pode ter influenciado no destino da comunidade: a não reeleição da prefeita no pleito de 2004.

Assim, a articulação dessas informações permite um segundo apontamento: a existência de uma cultura midiática. Estabelece-se essa afirmação na medida em que as relações políticas observadas estão ancoradas num fato midiático. A partir desse fato, a comunidade passou a questionar não apenas as ações da rádio, mas também a buscar outros canais de comunicação e 
participação política em que pudessem desenvolver a discussão desse episódio. Isso reforça o papel da mídia no cotidiano da comunidade, seja ela qual for.

Essa afirmação, entretanto, não deve ser levada a cabo e a efeito numa espécie de mecânica ideológica do pensamento. A reprodução das falas, a ideologia explícita no discurso do locutor, pode ou não ocorrer. Ademais, o fato de existir uma cultura midiática nessa comunidade apenas reforça as inúmeras apropriações da mídia pelos habitantes da cidade para resolução de seus problemas imediatos. Mas isso vai depender da mediação ${ }^{8}$, dos usos e gratificações que a comunidade faz dos produtos midiáticos que ela elabora e, de uma certa forma, a modela também. Essas apropriações podem ser ilustradas pelo uso de mídias mais rudimentares como a comunicação dialógica, direta, interpessoal. Como foi observado, a eficiência desse tipo de comunicação em Jataizinho atende não apenas o código cultural da cidade como também constitui num espaço importante de comunicação, mais democrática e participativa.

\section{Rádio Palanque}

Não é raro o uso de veículos de comunicação para fins particulares. Em se tratando de rádios comunitárias, restritos a pequenos espaços, como no caso de Jataizinho em que inexiste outro meio de comunicação massivo local, tal observação se torna ainda mais nítida. Chama atenção, entretanto, o uso político assumido pela Nova Geração.

Os que se utilizam do rádio como instrumento $\mathrm{F}_{-}$lítico, ou para fins religiosos, o fazem conscientes de seu poder persuasivo. Entretanto, mais ingênuo do que acreditar na manipulação das audiências é negligenciar o fato que de que a construção do imaginário coletivo se dê apenas pelos veículos de comunicação de massa. Os grupos de discussão, além dos dados das entrevistas mostraram outras formas de comunicação realizadas dentro daquela comunidade, a exemplo dos conselhos de bairro. Neste espaço, detectou-se a fonte das críticas das ações da rádio comunitária, cujas representações e serviços se apresentavam díspares em relação a grande parte da comunidade.

Seja pelo descontentamento dos ouvintes ao partidarismo assumido pela rádio comunitária, seja por formas mais interpessoais de comunicação, como as reuniões entre as diversas comunidades de Jataizinho - cujas reivindicações vão desde a construção de creches e postos de saúde, até a valorização dos artistas locais - observa-se nestes espaços o desejo por transformações daquela realidade.

Neste caso, a pouca participação dos ouvintes na produção dos programas da rádio comunitária pode ser observada como uma forma de protesto, nunca, porém, como apatia política. Os diversos patamares existentes de participação política (conscientização, participação, proposição, etc) impedem que se faça qualquer julgamento sobre a atividade política daquela comunidade. O que se verifica aqui são outros lugares, atores e formas de embate, dentro ou não dos meios de comunicação.

\section{Abstract}

The objective of this article is to recoup the history of the construction of the Communitarian Radio Nova Geração of Jatatizinho (PR), from the memory of the inhabitants of this locality. The methodology is the interpretation of a verbal historiografy, gotten through
${ }^{8}$ MARTín-BARBERO, Jesús. Dos meios às mediaçōes: comunicação, cultura e hegemonia. Rio de Janeiro (RI): Ed. UFRI, 1997. 
interviews and with the formation of two natural groups of quarrel. The narrative is structure at three moments: the construction of this media, its moment of worship and its amortization in the life of the community. The joint of the data of the research points with respect to an important factor and that it must be stood out for the understanding of the history of this communitarian media: the existence of a media culture in Jataizinho.

Keyswords: Communitarian communication, Verbal history, Media Culture, Communitarian radio Nova Generação, Jataizinho.

\section{Referências}

BAITELLO JÚNIOR, Norval. $O$ animal que parou os relógios. São Paulo: Annablume, 1999.

FOUCAULT, Michel. A ordem do discurso. $11^{a}$ ed. São Paulo: Ed. Loyola, 2004.

. A microfísica do poder. $14^{\mathrm{a}}$

Ed. Rio de Janeiro: Graal edições, 1999.

GEERTZ, Clifford. A interpretação das culturas. $1^{\text {a }}$ ed. Rio de Janeiro: Zahar Editor, 1976

INSTITUTOBRASILEIROGEOGRAFIA ESTATISTICA.Cidades@. Disponível em www.ibge.gov.br/cidadesat/ default.php. Acesso em: 15 set. 2005.

KELLNER, Douglas. Cultura das mídias. Bauru (SP): EDUSC, 2001.

BRASIL. Lei n ${ }^{\circ} 9.612 / 98$, Projeto de Lei no 1 , disponível em http://www.mc. gov.br/radcom. Acesso em 25/09/2005.
MANSANO, Fábio A. Para uma leitura crítica das rádios comunitárias. Universidade Estadual de Londrina (PR), 2003.

MARTÍN-BARBERO, Jesús. Dos meios às mediações: comunicação, cultura $\mathrm{e}$ hegemonia. Rio de Janeiro (RJ): Ed. UFRJ, 1997.

MOREIRA, Sônia V. Rádio Palanque, Rio de Janeiro (RJ): Mil Palavras, 1998.

NIETZSCHE, Friedrich. Para a genealogia da moral. Lisboa: Guimarães $\&$ Cia editores, $\mathrm{s} / \mathrm{d}$.

PEREIRA, Vitor Sorano; YAMAMOTO, Eduardo Y. Sujeito: Som: Representação: um estudo de recepção da Rádio Nova Geração de Jataizinho. Monografia apresentada como Trabalho de Conclusão de Curso. Universidade Estadual de Londrina (PR), 2004.

PROSS, Harry. La violência de los símbolos sociales. Trad: Vicente Romano. Barcelona: Antropos, 1983.

REIS, José Cezar dos. Estudo de uma comunidade pioneira no norte do Paraná: Jataizinho. 1950-1985. 1988. (Mestrado) - Assis: UNESP, 1988. Dissertação (Mestrado em História). Departamento de História, Universidade Estadual Paulista, Assis, 1988.

SANTAELlA, Lúcia. Cultura das mídias. $4^{\mathrm{a}}$ ed. São Paulo: Experimento, 1996.

WOLTON, Dominique. Pensar a comunicação. Tradução de Zélia Leal Adghirni. Brasília (DF): UnB, 2004.

Data do recebimento: 28/04/2008

Data do aceite: 10/05/2008 